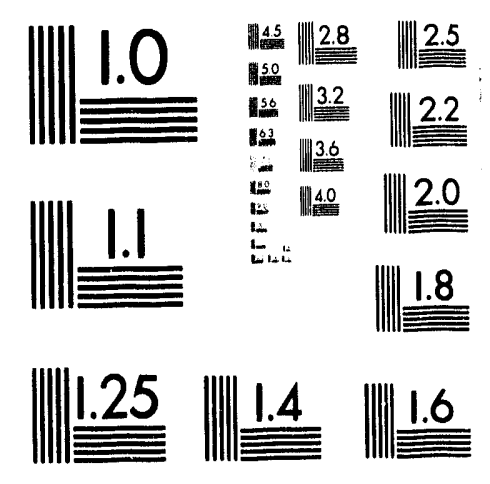



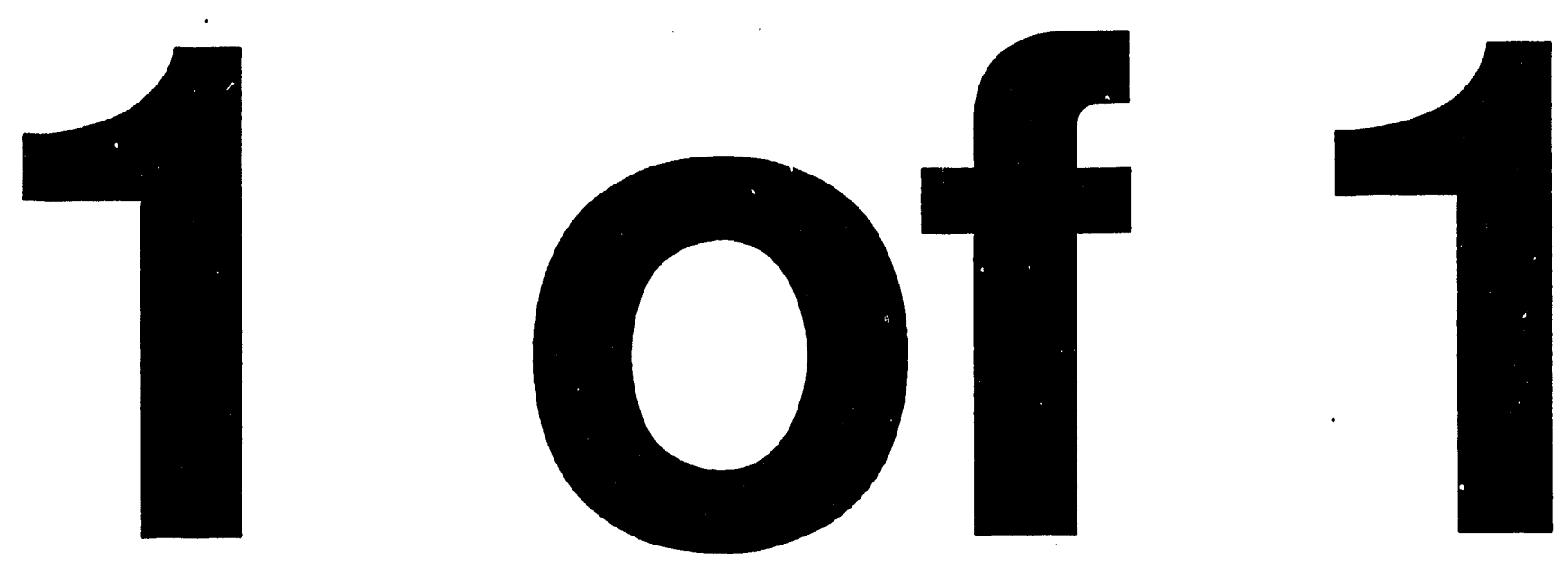


\title{
"ENVIRONMENTAL AND ECONOMIC ASSESSMENT OF DISCHARGES FROM GULF OF MEXICO REGION OIL AND GAS OPERATIONS"
}

Contract Number: DE-AC22-92MT92001

\author{
Continental Shelf Associates, Inc. \\ 759 Parkway Street \\ Jupiter, Florida 33477 \\ (407) $746-7946$
}

26 July 1993

Contract Date: 23 June 1992

Anticipated Completion Date: 22 June 1995

Government Award for Current Year: $\$ 3,153,659$

Program Manager and Principal Investigator:

David A. Gettleson, Ph.D.

Continental Shelf Associates, Inc.

\section{Technical Project Officer (COR): \\ Brent W. Smith, D.P.A. \\ U.S. Department of Energy \\ Metairie Site Office \\ 900 Commerce Road, East \\ New Orleans, Louisiana 70123 \\ (504) $734-4970$}

Yearly Technical Progress Report

Reporting Period: 23 June 1992 to 30 June 1993

and

June Monthly Status Report

Quarterly Technical Progress Report (April-June 1993)

Summary Report (June 1993)

Included Within

US/DOE Patent Clearance is not required prior to publication of this document. 


\section{TABLE OF CONTENTS}

EXECUTIVE SUMMARY $\ldots \ldots \ldots \ldots \ldots \ldots \ldots \ldots \ldots \ldots$

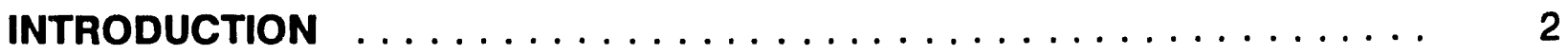

PROJECT DESCRIPTION $\ldots \ldots \ldots \ldots \ldots \ldots \ldots \ldots \ldots \ldots \ldots \ldots$

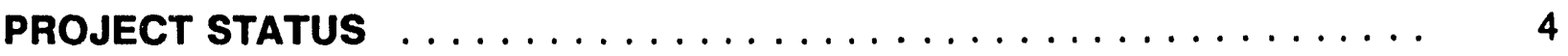

PLANNED ACTIVITIES $\ldots \ldots \ldots \ldots \ldots \ldots \ldots \ldots \ldots \ldots \ldots \ldots \ldots \ldots \ldots$

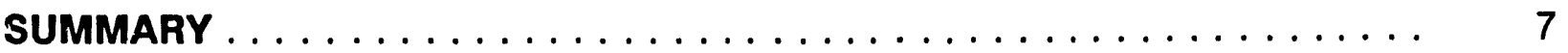

REPORT DISTRIBUTION LIST $\ldots \ldots \ldots \ldots \ldots \ldots \ldots \ldots \ldots \ldots$

REFERENCES AND APPENDICES (NONE)

PUBLICATIONS (NONE) 


\section{INTRODUCTION}

This report represents the first yearly technical summary for the study "Environmental and Economic Assessment of Discharges from Gulf of Mexico Region Oil and Gas Operations." Activities associated with Tasks 1 through 8 are discussed in this report. This report also serves as the June 1993 monthly and fourth quarterly technical progress report. 


\section{PROJECT DESCRIPTION}

Continental Shelf Associates, Inc. (CSA) was contracted to conduct a three-year study of the environmental and health related impacts of produced water and sand discharges from oil and gas operations. Data on naturally occurring radioactive materials (NORM), heavy metals, and hydrocarbons in water, sediment, and biota will be collected and evaluated. Health related impacts will be studied through field collections and analyses of commercially- and recreationally-important fish and shellfish tissues. Additionally, information on seafood catch, consumption, and use patterns for the Gulf of Mexico will be gathered and analyzed. The facilities to be studied will include both offshore and coastal facilities in the Gulf of Mexico.

Coastal sites will be additionally studied to determine ecological recovery of impacted wetland and open bay areas. The economic impact of existing and proposed effluent federal and state regulations will also be evaluated.

The primary objectives of the project are to increase the base of scientific knowledge concerning (1) the fate and environmental effects of organics, trace metals, and NORM in water, sediment, and biota near several offshore oil and gas facilities; (2) the characteristics of produced water and produced sand discharges as they pertain to organics, trace metals, and NORM variably found in association with the discharges; (3) the recovery of four terminated produced water discharge sites located in wetland and high-energy open bay sites of coastal Louisiana and Texas; (4) the economic and energy supply impacts of existing and anticipated federal and state offshore and coastal discharge regulations; and (5) the catch, consumption and human use patterns of seafood species collected from coastal and offshore waters. The products of the effort will be a series of technical reports detailing the study procedures, results, and conclusions which contribute to the transfer of technology to the scientific community, petroleum industry, and state and federal agencies. 


\section{PROJECT STATUS}

This study was initiated on 23 June 1992 with the signing of a contract between the U.S. Department of Energy (DOE) and Continental Shelf Associates, Inc. (CSA). CSA then signed subcontracts with Arthur D. Little, Inc. (ADL), Steimle and Associates, Inc. (SAI), ICF Resources Incorporated (ICF), and Florida Institute of Technology (FIT). Consultant agreements were also signed with Drs. Wayne Isphording and Bruce Honeyman.

Task 1 involves the establishment and a series of meetings with a Scientific Review Committee (SRC). The SRC was established in July. A Sampling and Analysis Plan (Task 2) was also prepared in July and the first week of August. The Plan described the activities to be conducted for Tasks 3 (Environmental Field Sampling and Analysis - Offshore), 4 (Monitoring of Recovery of Impacted Wetland and Open Bay Produced Water Discharge Sites), and 5 (Assessment of Economic Impacts of Offshore and Coastal Discharge Requirements on Present and Future Operations in the Gulf of Mexico Region). The Plan was submitted to the SRC members prior to a 20 August 1992 meeting. Additionally, a brief description of Task 6 (Synthesis of Gulf of Mexico Region Seafood Consumption and Use Patterns) was prepared and submitted to the SRC.

The purpose of this meeting was to present the Sampling and Analysis Plan and information for Task 6 to the SRC and receive verbal and later written comments. The primary comments involved delaying the Tasks 3 and 4 field sampling until the Spring of 1993 for the following reasons:

(1) improve coordination between the CSA team and Brookhaven National Laboratory (BNL) personnel regarding data needs for human health and ecological risk assessments,

(2) improve coordination between the CSA team/DOE and EPA,

(3) avoid offshore anoxic events, and

(4) assess and improve the selection of study sites.

Other comments were made regarding quality assurance, study design, produced sand samples, discharge plume tracking, use of hard banks for reference areas, and pore water collections.

The plans and mobilization activities for initiating sampling in late August early September were placed on hold due to the comments from the SRC members. A meeting was also scheduled between BNL and the CSA team to discuss data needs. 
A meeting was held on 14 September 1992 at CSA's office in Jupiter, Florida to define the data needs for the environmental and human health risk assessments to be conducted by BNL. It was agreed that platform (Task 3 - offshore) and site (Task 4 - coastal) selection, particularly due to the SRC comments and the disturbance caused by Hurricane Andrew's passage through Louisiana, should be re-examined and approached carefully. It was also agreed that because of the need to sample the fall and spring seasons (Task 4) that it was doubtful that a selection would be made in time to initiate fall sampling.

The following criteria for Task 4 site selection were determined at the meeting:

1) Determine if there are any sites in either Texas or East Louisiana (out of path of Hurricane "Andrew") that will terminate in early 1993 that could be surveyed (pre-termination) this Fall (1992).

2) Determine how many sites that will be terminated in mid to late 1993. These sites would be surveyed in the Spring of 1993 (pre-termination) and Fall of 1993 (post-termination or pre-termination - second survey).

3) If three to four sites have not been identified in items 1) and 2), determine existing open water sites that are discharging with no termination plans in 1993. Two samplings would potentially be conducted at these sites.

A second meeting was held in DOE's Metairie, Louisiana office on 15 December 1992 to discuss general sampling design and needed detection limits for radionuclides. Agreement was reached on these issues during the meeting between DOE, BNL, CSA, and SAI personnel.

A letter (23 December 1992) was sent to the SRC describing the revised general sampling design and detection limits. Several comments on the letter were received. A final sampling design was developed in conjunction with a re-costing of components for Tasks 3 and 4. This sampling design was sent to the SRC (17 March 1993) for comment. No substantial comments were received and work was initiated on revising the Sampling and Analysis Plan. Revisions to the Sampling and Analysis Plan have almost been completed.

As part of Task 2 (Sampling and Analysis Plan) an extensive effort was made to identify suitable sites and obtain permission to sample those sites under the Tasks 3 and 4 sampling activities.

For Task 3, CSA received a list of all offshore facilities that are discharging produced water in the Gulf of Mexico from EPA Region VI. The list was evaluated based on discharge levels (reported by EPA as daily maximum discharges), certain portions entered into a database with other data on radionuclide levels (previously 
received from industry), and sorted based on latitude/longitude, water depth, and availability of radionuclide data. A list of 53 potential candidate sites was selected based on the evaluation of the data.

The operators of the 53 facilities were contacted to determine their interest in cooperating in the study, verify the average discharge volume of produced water discharged, and determine availability of radionuclide data. This resulted in a short list of 19 facilities. A preferred list of these facilities was compiled based on discharge volume, geographic location, and water depth. The operators of these facilities were contacted for final approval. Additionally, six operators who operated 11 of the 19 facilities were requested to collect a produced water sample for determination of ${ }^{226} \mathrm{Ra}$ and ${ }^{228} \mathrm{Ra}$. Based on the second contact with the operators, 14 facilities with existing or recently collected NORM data were potentially available from which to choose eight discharging facilities for sampling. Eight platforms and six reference sites were selected following the criteria in the 17 March 1993 letter to the SRC.

Three sites were selected for Task 4 sampling foilowing the previously presented criteria. No sites were available in Texas as no operators planned to terminate their discharges on a time schedule that would iit the schedule for this study. Only two sites (open water) in Louisiana were identified and for which operator permission was obtained to sample that were outside the direct path of Hurricane Andrew and were terminating discharges on a schedule to allow for a spring 1993 pre-termination and fall 1993 post-termination sampling. A third site (canal site) was identified with a 1 January 1994 termination. This site will be sampled in fall 1993 (pre-termination) and spring 1994 (post-termination).

Task 3 sampling was initiated on 3 June 1993. Due to several weather delays and sariple collection problems, the cruise was behind schedule at the end of June.

Task 4 sampling (pre-termination) at the Delacroix Island site was completed during April and Bay de Chene sampling during May. All samples have been shipped to the laboratories and analyses are in progress.

Task 5 activities that have been completed include the following: 1) developing a detailed plan for completion of the proposed effort, 2) acquiring all of the historical production data for the coastal, state waters, and Federal OCS fields for the analysis, 3) evaluating (preliminary) methodology for model, 4) developing decline curve forecast of production for Louisiana coastal and state water fields, and 5) acquiring platform database for Federal OCS fields.

Task 6 activities included the design and field testing of all surveys with the exception of the oyster producers survey. Personnel who administer the surveys were trained. The summer fisherman surveys were initiated and are currently ongoing. The surveys of wholesalers and processors have been mailed and replies are currently being received. Several of the summer surveys of retailers have been performed. The 
Louisiana Restaurant Associates was provided with the restaurant survey for distribution to members.

Task 7 activities have been delayed due to the delays associated with Tasks 3 and 4 and the cancellation of the Minerals Management Service (MMS) Gulf of Mexico Information Transfer Meeting. An abstract for the Task 3 sampling program was prepared and submitted to the Society of Environmental Toxicology and Chemistry. Additionally, a presentation was scheduled at the DOE Contractor Review Meeting in Oklahoma.

Task 8 activities involved project management and delivery of all required reports. Revised management, milestone schedule, and cost plans are being developed. An expanded quality assurance/quality control program in the area of radioactive nuclei was developed. 


\section{PLANNED ACTIVITIES}

Either one or two SRC meetings (Task 1) will be held during the next year. The schedule for the meetings is being developed during the preparation of the revised program schedule.

The Sampling and Analysis Plan will be completed in July/August and copies will be distributed to the SRC members.

The Task 3 cruise should be completed by the end of July with sample analyses completed approximately four months after cruise completion. Data analyses and report writing should be completed by July 1994.

Task 4 activities will include sampling in fall 1993 and spring 1994. Laboratory analyses of the spring and fall 1993 samples should be completed by July 1994.

Task 5 activities over the next year will include the following: 1) prepare production forecast for all fields in coastal, state waters, and Federal OCS areas of the Gulf of Mexico, 2) characterization of undiscovered fields in state and federal waters, 3) characterization of existing production facilities and treatment technologies, 4) quantify impact of current regulations on future oil and gas production in the Gulf, and 5) quantify impact of future regulations on currently producing oil and gas fields and undiscovered fields in the Gulf. It is anticipated the project will be completed in March 1994.

Task 6 activities will include designing, field testing, training personnel, and executing the oyster producer survey. The Texas Restaurant survey will also be performed. Fisherman surveys will continue to be performed. The wholesaler/processor survey forms will continue to be received. Data analyses will be performed and it is anticipated that a draft report should be available by May 1994.

Task 7 activities will include attendance and presentations at the DOE Contractor Review Conference in July. A presentation will also be made in August at a Gulf of Mexico Program (EPA) Toxic Substances Subcommittee Workshop on Research Needs in the Gulf of Mexico. It is also anticipated that presentations will be made at the MMS Gulf of Mexico Information Transfer Meeting this year.

Task 8 activities will include finalizing the revised management, milestone schedule, and cost plans. All required reporting will also be accomplished. 


\section{EXECUTIVE SUMMARY}

Task 1 (Scientific Review Committee) activities included the establishment of and meeting with the Scientific Review Committee (SRC) to review the draft Sampling and Analysis Plan. The SRC was also provided with revisions to the draft Sampling and Analysis Plan. Task 2 (Sampling and Analysis Plan) work involved finalizing the selection of sampling sites, redesigning the offshore and coastal sampling program, and redefining needed detection levels of radium. Task 3 (Environmental Field Sampling and Analysis of NORM, Heavy Metals, and Organics) activities included cruise mobilization and initiation of the field collection of the samples and data specified in the Sampling and Analysis Plan. Task 4 (Monitoring of the Recovery of Impacted Wetland and Open Bay Produced Water Discharge Sites in Coastal Louisiana and Texas) activities included the early summer field sampling of two of the three selected facilities in Louisiana prior to their termination of produced water discharges. Task 5 (Assessment of Economic Impacts of Offshore and Coastal Discharge Requirements on Present and Future Operations in the Gulf of Mexico Region) activities included acquiring the needed historical production data and federal platform database, developing a production forecast for Louisiana coastal and state water fields, and evaluating methodology for additional modeling efforts. Task 6 (Synthesis of Gulf of Mexico Seafood Consumption and Use Patterns) work items involved designing, field testing, and initiation of all surveys with the exception of the oyster producers survey. Task 7 (Technology Transfer Plan) activities included scheduling the presentation of information concerning this project at the DOE Contractor Review Meeting in Oklahoma and submitting an abstract for a Society of Environmental Toxicology and Chemistry meeting. Task 8 (Project Management and Deliverables) activities have involved the submission of the required reports and routine management. An expanded quality assurance/quality control program in the area of radioactive nuclei was developed. 


\section{SUMMARY}

Task 1 activities included the establishment of and meeting with the Scientific Review Committee (SRC) to review the draft Sampling and Analysis Plan. The SRC was also provided with revisions to the draft Sampling and Analysis Plan. Task 2 work involved finalizing the selection of sampling sites, redesigning the offshore and coastal sampling program, and redefining needed detection levels of radium. Task 3 activities included cruise mobilization and initiation of the field collection of the samples and data specified in the Sampling and Analysis Plan. Task 4 activities included the early summer field sampling of two of the three selected facilities in Louisiana prior to their termination of produced water discharges. Task 5 activities included acquiring the needed historical production data and federal platform database, developing a production forecast for Louisiana coastal and state water fields, and evaluating methodology for additional modeling efforts. Task 6 work items involved designing, field testing, and initiation of all surveys with the exception of the oyster producers survey. Task 7 activities included scheduling the presentation of information concerning this project at the DOE Contractor Review Meeting in Oklahoma and submitting an abstract for a Society of Environmental Toxicology and Chemistry meeting. Task 8 activities have involved the submission of the required reports and routine management. An expanded quality assurance/quality control program in the area of radioactive nuclei was developed. 

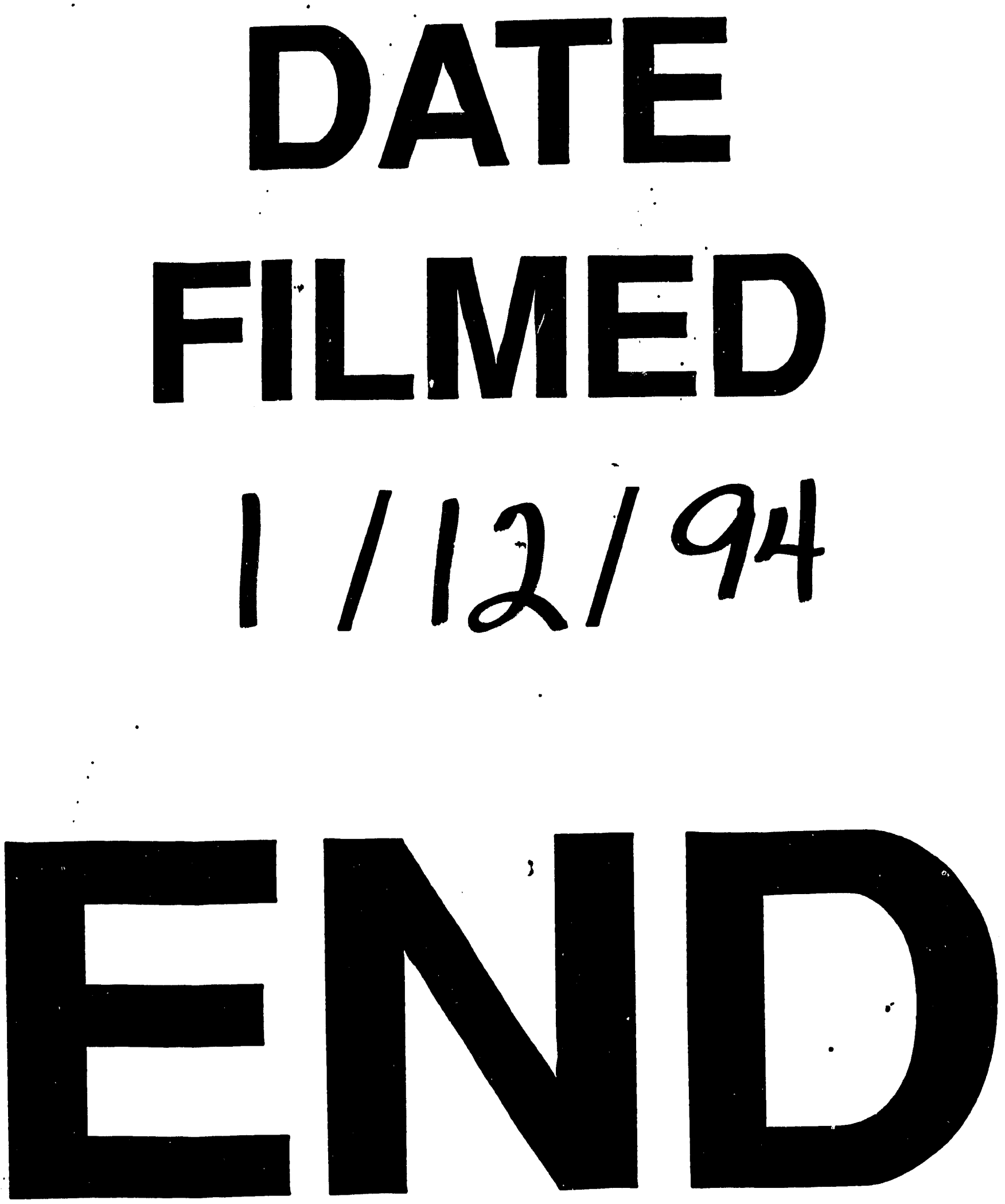
